\title{
Knowledge and Compliance Levels Regarding Hand Hygiene Practices among Nurses in the Neonatal Intensive Care Unit (NICU) of the Princess Margaret Hospital, Nassau, Bahamas
}

\author{
Dorothea Francis ${ }^{1}$, Philip Onuoha ${ }^{1}$, Esther Daniel $^{1} \&$ Virginia Victor ${ }^{1}$ \\ ${ }^{1}$ The UWI School of Nursing, Faculty of Medical Sciences, University of the West Indies, St. Augustine, Trinidad \\ and Tobago \\ Correspondence: Philip Onuoha, The UWI School of Nursing, Faculty of Medical Sciences, University of the \\ West Indies, St. Augustine, Trinidad and Tobago.
}

Received: August 22, 2020 Accepted: September 21, 2020 Online Published: October 24, 2020

doi:10.5539/gjhs.v12n13p19 URL: https://doi.org/10.5539/gjhs.v12n13p19

\begin{abstract}
Purpose: The purpose of this study was to assess knowledge and compliance levels of hand hygiene among registered nurses at the Princess Margaret Hospital, Neonatal Intensive Care Unit (NICU), Nassau, Bahamas.

Method: A cross-sectional survey was conducted in June 2019. A 32-item self-administered questionnaire was provided to 40 registered nurses to assess their knowledge and compliance levels to hand hygiene practices.

Results: All respondents were females. The results showed that $45 \%$ of the nurses had excellent knowledge, $27.5 \%$ had good knowledge on hand hygiene, while $27.5 \%$ had an average knowledge level. There was a statistically significant association between their knowledge level and their age, years of experience, length of time in the NICU and their level of education $(\mathrm{p} \leq 0.05)$. There was no statistically significant association between their compliance level and their socio-demographics ( $\mathrm{p} \geq 0.05)$.
\end{abstract}

Conclusions: Nurses' knowledge levels were rated as good and so were their practice levels.

Keywords: health care professionals, knowledge, compliance, nosocomial infection, hand hygiene

\section{Introduction}

Princess Margaret Hospital (PMH) is a tertiary level training hospital located on the island of New Providence, Bahamas - a developing country in the Caribbean. It services the entire Bahamas - an archipelago of seven hundred (700) islands and cays with a population of about 350,000. It contains a sixty (60) bed Level III Neonatal Intensive Care Unit (NICU) that serves premature and ill neonates from the Bahamas and Turks and Caicos Islands. The unit admits on average approximately 450 babies per year (Bahamas Department of Statistics, 2014).

As a Neonatal Intensive Care Unit (NICU), almost all infants that are admitted require extensive and specialized care that the average newborn may not need. The admission team consists of physicians, nurses and support staff who are responsible for achieving and maintaining stability by using the proper life saving measures to ensure optimal levels of health. The World Health Organization (WHO, 2017), sanctions that healthcare professionals (HCP) should practice hand asepsis before and after patient care, after removing gloves, before performing a sterile procedure, and after touching the patients' environment to stop the transmission of microorganisms to patients and hand hygiene is the most effective, simplest, and least expensive way to prevent the spread of hospital infections (Abedi et al., 2020). Additionally, guidelines have been published that also speaks to proper hand hygiene in healthcare, with hopes of increasing patient security by ensuring safe practices (Cook, Marchaim and Kaye, 2011). The Center for Disease Control (CDC, 2017) affirms that contaminated hands have been known to spread organisms to patients. However, we believe that basic aseptic technique may be sometimes overlooked in the rush of crisis care. Caregivers are almost programmed to think that once the patient attains cardio-respiratory stability, less attention is paid to other factors like infection control.

We know that hospital acquired infection (HAI) or nosocomial infection do occur and these infections are more frequent than bacterial infections (WHO, 2011). Nosocomial infections are one of the main reasons for illness and death of neonates in the NICU. In addition, lengthy hospital stays increase cost and devastation for parents are all common to the above (Mayhall, 2005). They are a threat globally and all institutions take pride in ensuring that 
healthcare professionals have a ground to stand on in terms of its' management. Numerous scholars have determined that HAIs are spread more frequently from one patient to another by way of dirty palms of hospital staff (Findik, Ceylan, and Elmastas, 2011; Mehta, Rai, Rai, Bicanic and Watal, 2011). Hand hygiene is an essential step to preventing the spread of germs (abedi et al. 2020; CDC 2014).

This study explored knowledge and compliance levels of Registered Nurses to hand hygiene practices.

\subsection{The Problem}

In 1996 and 2012, there was an infection outbreak in the NICU. These incidents have led to reforms including relocation of the unit and subsequently construction of a modern facility. Other initiatives were implemented such as development and revision of policies, enhanced scheduling staffing practices, and targeted training of staff with up-scaling of environmental practices. Despite these strides, nosocomial infection remains a challenge within the NICU. HAIs affects the quality of health care and is a major source of adverse healthcare outcomes leading to morbidity, increase in admissions and healthcare cost. In addition, healthcare can be further comprised by pain and suffering of critically ill newborns with an increase in mortality rate. Today, the numbers in the NICU New Providence, has steadily increased as reflected by the report from the infection control unit of the Princess Margaret Hospital, Nassau, Bahamas. It is important for nurses to adhere to the policies and guidelines, of the NICU in order to prevent and eliminate infections. Registered Nurses working in the NICU are in constant contact with critically ill neonates who totally rely on them to deliver efficient healthcare to meet their needs daily. Improper hand asepsis has been recognized as the primary cause of spreading microbes in hospitals in developing countries (WHO, 2017). Studies have established links between knowledge and hand hygiene practices (Findik, Ceylan, and Elmastas, 2011; Mehta, Rai, Rai, Bicanic and Watal, 2011). NICUs are distinctive healthcare settings whereby most neonates are premature or affected by serious conditions and are extremely vulnerable to infections. Such neonates with immature immune functions and weakened defense system are exposed to frequent invasive techniques and intensive handling by HCPs daily. HAIs today are persistent causes of sickness and death within the NICU. HH is the cheapest method to stop the spread of HAIs, yet it is one of the hardest quality measures to monitor (CDC 2017; CDC, 2012, Mick, 2011). Today, there are no documented studies of this issue in the Bahamas hence we undertake to document the nurse's knowledge and compliance levels to hand hygiene policy in the NICU of the Princess Margaret Hospital, New Providence, Bahamas.

The theoretical interplay among the elements of Theory of Planned Behaviour (Ajzen, 1991); i.e. (a) behavioral beliefs-strength and outcome evaluations, (b) normative beliefs-strength and motivation to comply, and (c) control beliefs-strength and perceived power; provides the underpinning on the extent of compliance to HAI policies among the nurses in this hospital. Thus, to what extent do the nurses' beliefs motivate them to comply with the policies of HAI? This conjecture is put to test in this study. For example, if the nurses on one hand believe that exposure to maternal infections, neonatal factors, and use of invasive methods and devices can prone their patients to HAIs, and on the other hand if they believe that the use of routine control such as hand hygiene practices, will reduce significantly the HAIs for their patients (Vermeil et al, 2019; Ajzen, 1991, Polin, Denson and Brady, 2012; Mitra, Mullany, Harrison, et al. 2018; Ramasethu, 2017; Jeon g, Jeong and Choi, 2006; WHO, 2011; Al-Rawajfah, Hewitt, Stetzer and Cheema, 2012; Arsan, Erayman, Kirdar, Yukksekkaya, Cimen \& Tuncer et al. 2010; Cando, Dennehy Halverson, Fishman, Kohn and Murphy, 2010; McLaughlin, Walsh, 2012; Parmeggiani, Abbate, Marinelli and Angeilillo, 2010; Korniewicz and El-Masri, 2010).

\subsection{Aim}

The aim of this study was to ascertain the knowledge and compliance levels to hand hygiene practices among nurses in the NICU of the Princess Margaret Hospital, Nassau, Bahamas.

\subsection{Objectives}

- To determine the nurses' knowledge levels regarding the hand hygiene policy at the Princess Margaret Hospital, Nassau, Bahamas.

- To determine the nurses' compliance levels regarding hand hygiene policy at the Princess Margaret Hospital, Nassau, Bahamas.

- To determine if there is a relationship between (a) knowledge of policies and (b) compliance to Hand Hygiene Policies among registered nurses at the hospital; and their selected Socio-demographic variables.

\section{Research Approach and Design}

This research utilized a descriptive cross-sectional design. It described the variables and explored the relationship between variables using quantitative statistical analysis (Polit \& Beck, 2014). 


\subsection{Population for the Study}

This study was undertaken at a Bahamian NICU of The Princess Margaret Hospital, a tertiary level training hospital located in Nassau, Bahamas a developing country in the Caribbean. It services the entire Bahamas, an archipelago of 700 islands and cays with a population of about 350,000. It contains a 60-bed Level III NICU that serves premature and ill neonates from The Bahamas and the Turks and Caicos Islands. The unit provides intensive and intermediate care to approximately 450 babies per year (Bahas Department of Statistics, 2014).

Nursing care is delivered by approximately 51 registered nurses (RNs) who work eight- and ten-hour shifts. The patient to nurse ratio is about 4-3:1 but may be 1:1 or 2:1 for critically ill patients. The length of stay for patients admitted to the unit was about 20 days in 2017 (Princess Margaret Hospital, 2017).

All 51 registered nurses were targeted for the study however, only 40 registered nurses competed and returned the questionnaire. We note that two (2) registered nurses were on extended study leave out of the country, 3 registered nurses migrated, and one (1) registered nurse was hospitalized, who later died (WHO, 2017).

\subsection{Ethical Consideration}

Ethical approval and clearances were received from the Public Hospitals Authority and the University of The West Indies (UWI) Ethics Committee and the Public Hospitals Authority and the Princess Margaret Hospital, New Providence, Bahamas. Consent and permission were sought and received from the research participants who also were required to sign informed consent.

\subsection{Instrument}

\subsubsection{Description of the Tool}

Information were gathered using a 32-item self-administered questionnaire adapted mainly from the World Health Organization (WHO, 2017). This pre-validated instrument from consisted of; section A with 16 demographic items, section B contained 10 items on healthcare professionals training history and knowledge about infection control practices. Section $\mathrm{C}$ had 5 items on the healthcare professionals' level of compliance. This section of the questionnaire consisted of five major constructs that supported hand washing: i. before touching a patient, ii. Before clean/aseptic procedures, iii. After body fluid exposure/risk, iv. After touching a patient, and v. after touching patient surroundings. This tool was very easy to use and indicated the critical moments when healthcare workers should perform the hand washing.

\subsubsection{Scoring of the Tool}

Scoring of the tool was done and grouped according to knowledge level and compliance level responses. Questions were created on the basic concepts, content, and activity requirements of hand hygiene and universal precautions, covering 27 items, with possible responses of 'yes' and 'no'. 'Yes' was given a value of 1 point, and 'no' with 0 points; the maximum possible score was 27 . The higher the score, the greater the assumed knowledge about hand hygiene and universal precautions the participant has. The levels of knowledge were categorized as follows; 20 27 as "Excellent Knowledge", $13-19$ as "Good Knowledge", 6-12 as "Average Knowledge", and $1-5$ as "Poor Knowledge" (Table 1).

Table 1. Showing the marking scale for the knowledge questions

\begin{tabular}{ll}
\hline Knowledge Scale & Range \\
\hline Excellent Knowledge & $20-27$ \\
Good Knowledge & $13-19$ \\
Average Knowledge & $6-12$ \\
Poor Knowledge & $1-5$ \\
\hline
\end{tabular}

The compliance level questions consisted of five (5) sections with a total of thirty-two (32) questions. Step one 1 has 8 questions, step 2 has 5 questions, step 3 has 5 questions, step 4 has 8 and step 5 has 6 items. The participants had to tick one of the five (5) responses, which included 'always', 'frequently' 'most of the time' 'sometimes' and 'never'. The greater the score, the better the assumed compliance level of hand hygiene the participant has. In determining the level of compliance, the following scaling was used; total score of between $26-32$ is rated as "Always Compliant", $19-25$ as "Frequently Compliant", $13-18$ as "Most of the time Compliant", 7 - 12 as "Sometimes Compliant and $1-6$ as "Never Compliant". The findings of the Compliance Level responses were 
further assessed using Likert scales so numerical statistical calculations could be made and interpretations concluded (Table 2).

Table 2. Showing the marking scale for the compliance questions

\begin{tabular}{ll}
\hline Compliance Scale & Range \\
\hline Always compliant & $26-32$ \\
Frequently compliant & $19-25$ \\
Most of the time compliant & $13-18$ \\
Sometimes compliant & $7-12$ \\
Never compliant & $1-6$ \\
\hline
\end{tabular}

\subsubsection{Procedure for Data Collection and Analysis}

Information was collected over a period of two (2) weeks after all required ethical approvals were obtained. The collected data was coded, classified, summarized, and analyzed using the SPSS Version 23 which is a data management and analysis invention produced by IBM SPSS, Inc. in Chicago, Illinois. Data was subjected to descriptive and inferential statistical analysis as appropriate and presented as frequencies based on the research objectives. A P-Value equal to or less than 0.05 was considered statistically significant (Rose, Spinks and Canhoto, 2015).

\section{Result}

\subsection{Demographic Characteristics}

Table 3 shows the frequency distribution of the demographic characteristics of the study participants. All respondents were females who worked in the Neonatal Intensive Care Unit (NICU) at PMH in The Bahamas. Their nationality was mostly Bahamian (76.9\%). Most have work experience 5-10 year (30\%) followed by over 20 years $(28.2 \%)$ and $76.5 \%$ of the nurses have degrees or post graduate degree as their highest professional qualification.

Table 3. Frequency and percent distribution of sociodemographic characteristics $\mathrm{N}=40$

\begin{tabular}{lll}
\hline Variables & $\mathrm{n}$ & $\%$ \\
\hline Nationality & 30 & 76.9 \\
Bahamian & 9 & 23.1 \\
Non- Bahamian & 1 & \\
\hline Age & 16 & 2.6 \\
$<25$ years & 6 & 42.1 \\
$25-34$ years & 12 & 15.8 \\
$35-44$ years & 3 & 31.6 \\
$45-54$ years & 7 & 7.9 \\
$55-64$ years & 72 & 17.9 \\
\hline Years of Nursing experience in current post & 5 & 30.8 \\
$<5$ years & 4 & 12.8 \\
$5-10$ years & 11 & 10.3 \\
$11-15$ years & & 28.2 \\
$16-20$ years & 3 & 7.7 \\
Over 20 years & & \\
\hline Highest level of Qualification & & \\
Nursing Diploma & & \\
\hline
\end{tabular}




\begin{tabular}{lll}
\hline ASc in Nursing & 14 & 35.9 \\
BSc in Nursing & 16 & 41.0 \\
MS in Nursing & 6 & 15.4 \\
\hline Participate in a session on hand hygiene for the NICU & \\
Yes & 24 & 60.0 \\
No & 16 & 40.0 \\
\hline Length of time working in NICU & & \\
$<1$ year & 4 & 10.3 \\
$1-4$ years & 10 & 25.6 \\
$5-10$ years & 12 & 30.8 \\
$11-15$ years & 7 & 17.9 \\
$16-20$ years & 4 & 10.3 \\
Over 20 years & 2 & 5.1 \\
\hline
\end{tabular}

\subsection{Nurses Knowledge Levels related to HAI}

Tables 4 depicts the frequency responses of the respondents on the individual items on knowledge of hand hygiene. These responses are further s summarized in figure 1. As can be observed, most (47.5\%) of the nurses have good knowledge followed by $35.5 \%$ of them who had Good knowledge while $15 \%$ had Excellent knowledge.

Table 4. Responses to Questions Regarding Knowledge level on hand hygiene

\begin{tabular}{|c|c|c|c|}
\hline Knowledge Items & Correct Answer & $\begin{array}{l}\text { Frequency } \\
\text { Correct } \\
\text { Response } \\
\text { (n)\% }\end{array}$ & $\begin{array}{l}\text { Frequency } \\
\text { Incorrect } \\
\text { Response } \\
\text { (n)\% }\end{array}$ \\
\hline $\begin{array}{l}\text { Received formal training on hand hygiene in the last three (3) } \\
\text { years }\end{array}$ & yes & (24) 60.0 & (16) 40.0 \\
\hline $\begin{array}{l}\text { Do you routinely use an alcohol-based hand rub for hand } \\
\text { hygiene }\end{array}$ & yes & (33) 82.5 & (7) 17.5 \\
\hline $\begin{array}{l}\text { Main route of cross-transmission of potentially harmful germs } \\
\text { between patients in a health-care facility }\end{array}$ & Hands when not clean & (31) 77.5 & (9) 22.5 \\
\hline $\begin{array}{l}\text { What is the most frequent source of germs responsible for } \\
\text { health care-associated infections? }\end{array}$ & $\begin{array}{l}\text { Germs present on or } \\
\text { within the patient }\end{array}$ & (13) 32.5 & (27) 67.5 \\
\hline $\begin{array}{l}\text { Which of the following hand hygiene actions prevents } \\
\text { transmission of germs to the patient? }\end{array}$ & True & (33) 82.5 & (7) 17.5 \\
\hline \multicolumn{4}{|l|}{ Before touching a patient } \\
\hline Immediately after a risk of body fluid exposure & True & (19) 47.5 & (21) 52.5 \\
\hline After exposure to the immediate surroundings of a patient & True & (5) 12.5 & (35) 87.5 \\
\hline Immediately before a clean/aseptic procedure & True & (22) 55.0 & (18) 45.0 \\
\hline $\begin{array}{l}\text { Which of the following hand hygiene prevents transmission of } \\
\text { germs to the health-care workers? }\end{array}$ & True & (28) 70.0 & (12) 30.0 \\
\hline \multicolumn{4}{|l|}{ After touching a patient } \\
\hline Immediately after a risk of body fluid exposure & True & (23) 57.5 & (17) 42.5 \\
\hline Immediately before a clean/aseptic procedure & False & (6) 15.0 & (34) 85.0 \\
\hline After exposure to the immediate surroundings of a patient & True & (26) 65.0 & (14) 35.0 \\
\hline
\end{tabular}


Which of the following statements on alcohol-based hand rub $\&$ hand washing with soap \& water are true?

Hand rubbing is more rapid for hand cleansing than hand washing

\begin{tabular}{|c|c|c|c|}
\hline Hand rubbing causes skin dryness more than hand washing & False & (13) 32.5 & (27) 67.5 \\
\hline $\begin{array}{l}\text { Hand rubbing is more effective against germs than hand } \\
\text { washing }\end{array}$ & False & (19) 47.5 & (21) 52.5 \\
\hline $\begin{array}{l}\text { Hand washing and hand rubbing are recommended to be } \\
\text { performed in sequence }\end{array}$ & False & (8) 20.0 & (32) 80.0 \\
\hline $\begin{array}{l}\text { The minimal time needed for alcohol-based hand rub to kill } \\
\text { most germs on your hand }\end{array}$ & 20 seconds & (19) 47.5 & (21) 52.5 \\
\hline $\begin{array}{l}\text { Which type of hand hygiene method is required in the } \\
\text { following situations? }\end{array}$ & Rubbing & (13) 32.5 & (27) 67.5 \\
\hline \multicolumn{4}{|l|}{ Before palpation of the abdomen } \\
\hline Before giving an injection & Rubbing & (8) 20.0 & (32) 80.0 \\
\hline After emptying a bedpan & Washing & (39) 97.5 & (1) 2.5 \\
\hline After removing examination gloves & Washing & 87.5 & (5) 12.5 \\
\hline After making a patient's bed & Washing & (31) 77.5 & (9) 22.5 \\
\hline After visible exposure to blood & Washing & (39) 97.5 & (1) 2.5 \\
\hline $\begin{array}{l}\text { Which of the following should be avoided, as associated with } \\
\text { increased likelihood of colonization of hands with harmful } \\
\text { germs? }\end{array}$ & True & (33) 82.5 & (7) 17.5 \\
\hline \multicolumn{4}{|l|}{ Wearing jewellery } \\
\hline Damaged skin & True & (28) 70.0 & (12) 30.0 \\
\hline Artificial fingernails & True & (36) 90.0 & (4) 10.0 \\
\hline Regular use of a hand cream & False & (12) 30.0 & 70.0 \\
\hline
\end{tabular}

Figure 1. Mean Knowledge Scores of the Nurses related to $\mathrm{HAl}: \mathrm{N}=41$

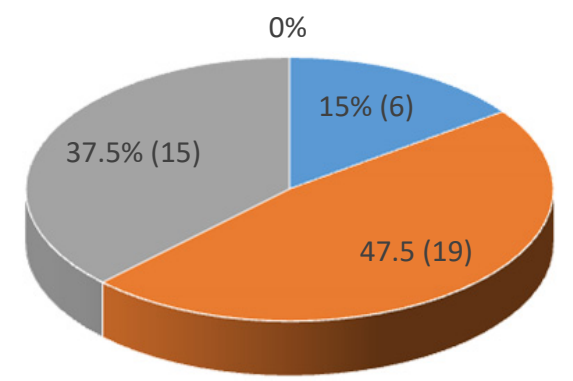

- Excellent Knowledge - Good Knowledge - Average Knowledge = Poor Knowledge

Figure 1. Pie Chart showing Mean Knowledge Scores of Respondents 


\section{Nurses' Compliance Levels to the Policies of HAI}

Figure 2 summarizes tables 5, 6, 7, 8 and 9 regarding the nurses' compliance levels to the HAI using the 5-step recommendation of the WHO. As can be observed the nurses' compliance with step 1 was highest at (4.9), followed with their compliance with Step 1 (4.69), then step 4 at (4.65), step 2 at 4.48 and step 5 at (4.14).

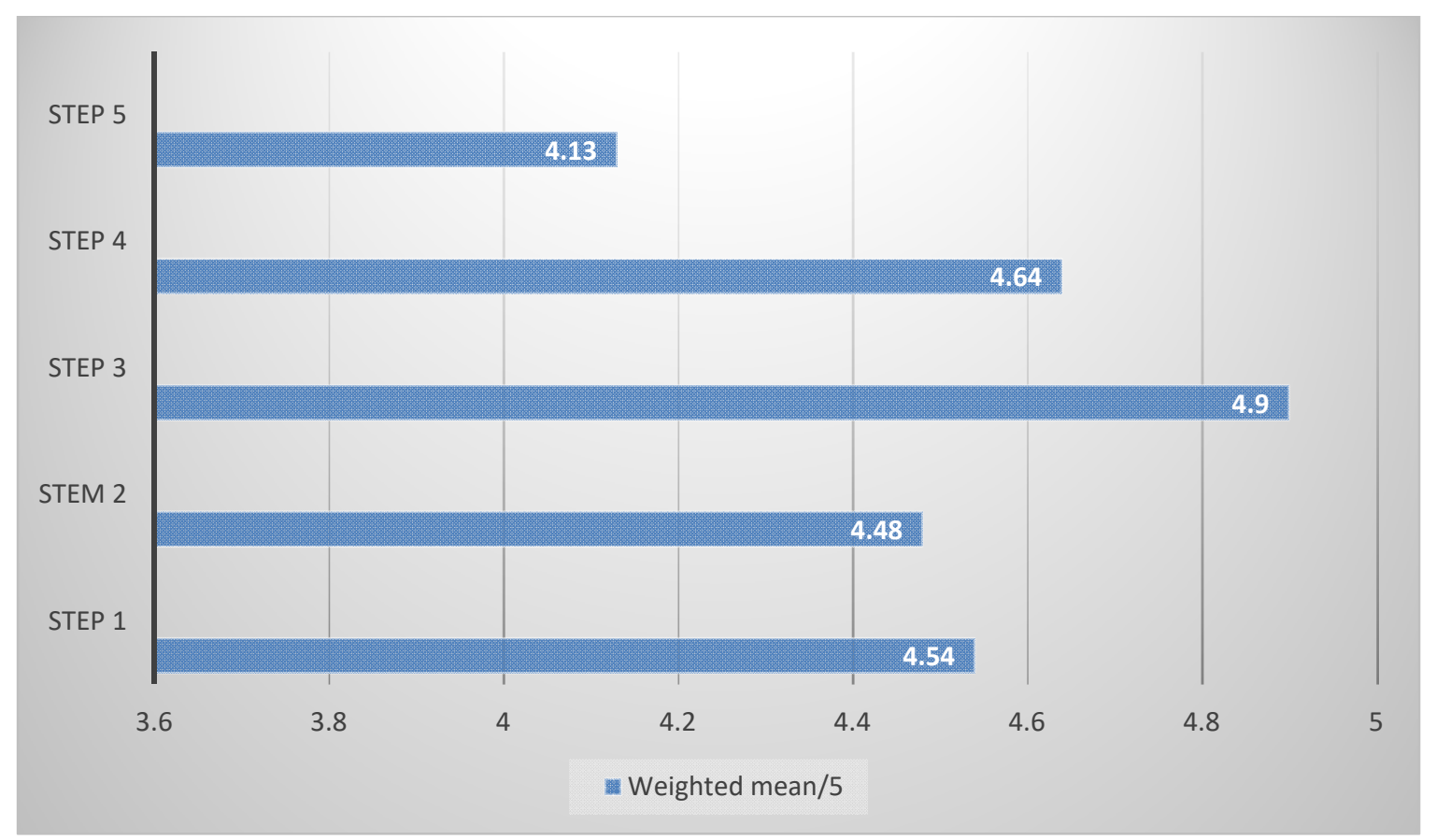

Figure 2. The mean of means of the Nurses' Compliance to HAI According to the 5 Steps: $N=41$; Maximum 5 
Table 5. Compliance level responses of the respondents for step 1 about hand hygiene practice $($ Mean of mean $=$ 4.69)

\begin{tabular}{|c|c|c|c|c|c|c|c|}
\hline \multicolumn{8}{|c|}{ Degree of Compliance } \\
\hline $\begin{array}{l}\text { Step } 1 \\
\text { Before Touching a patient }\end{array}$ & $\begin{array}{l}\text { Always } \\
\text { (n) } \%\end{array}$ & $\begin{array}{l}\text { Frequently } \\
\text { (n) } \%\end{array}$ & $\begin{array}{l}\text { Most of } \\
\text { the } \\
\text { time } \\
\text { (n) } \%\end{array}$ & $\begin{array}{l}\text { Sometimes } \\
\text { (n) } \%\end{array}$ & $\begin{array}{l}\text { Never } \\
\text { (n) } \%\end{array}$ & $\begin{array}{l}\text { No } \\
\text { Response }\end{array}$ & $\begin{array}{l}\text { Weighted } \\
\text { mean } \\
(\mathrm{WM})\end{array}$ \\
\hline I wash my hands upon arrival for duty & $\begin{array}{l}(30) \\
75.0\end{array}$ & (9) 22.5 & (0) 0 & (1) 2.5 & (0) 0 & & 4.70 \\
\hline $\begin{array}{l}\text { I wash my hands on entering a patient's } \\
\text { room before patient contact }\end{array}$ & $\begin{array}{l}(25) \\
62.5\end{array}$ & (9) 22.5 & $\begin{array}{l}(5) \\
12.5\end{array}$ & (1) 2.5 & (0) 0 & & 4.44 \\
\hline $\begin{array}{l}\text { I wash my hands before } \\
\text { Documentation }\end{array}$ & $\begin{array}{l}(14) \\
35.8\end{array}$ & (13) 33.3 & $\begin{array}{l}4) \\
10.2\end{array}$ & (7) 17.9 & $\begin{array}{l}(1) \\
2.5\end{array}$ & 1 & 3.79 \\
\hline $\begin{array}{l}\text { I wash my hands after blowing or } \\
\text { wiping my nose }\end{array}$ & $\begin{array}{l}(32) \\
82.0\end{array}$ & (4) 10.2 & (2) 5.1 & (1) 2.5 & (0) 0 & 1 & 4.71 \\
\hline I wash my hands before and after eating & $\begin{array}{l}9(38) \\
95.0\end{array}$ & (2) 5.0 & (0) 0 & (0) 0 & (0) 0 & & 4.95 \\
\hline $\begin{array}{l}\text { I wash my hands before and after } \\
\text { toileting }\end{array}$ & $\begin{array}{l}(37) \\
92.5\end{array}$ & (3) 7.5 & (0) 0 & (0) 0 & (0) 0 & & 4.92 \\
\hline $\begin{array}{l}\text { Before performing a physical } \\
\text { non-invasive examination: taking pulse, } \\
\text { blood pressure, chest auscultation, } \\
\text { recording ECG }\end{array}$ & $\begin{array}{l}(24) \\
55.0\end{array}$ & (13) 37.5 & (2) 5.0 & (1) 2.5 & (0) 0 & & 4.50 \\
\hline $\begin{array}{l}\text { Before delivering care and other } \\
\text { non-invasive treatment: applying } \\
\text { oxygen mask, giving a massage }\end{array}$ & $\begin{array}{l}(21) \\
47.5\end{array}$ & $\begin{array}{l}(12) \\
35.0\end{array}$ & $\begin{array}{l}6) \\
15.0\end{array}$ & $\begin{array}{l}(1) \\
2.5\end{array}$ & $\begin{array}{l}(0) \\
0\end{array}$ & & 4.32 \\
\hline
\end{tabular}

Table 6. Compliance level responses of the respondents for step 2 about hand hygiene practice Mean of mean $=4.48$ )

\begin{tabular}{|c|c|c|c|c|c|c|c|}
\hline & Degree c & Compliance & & & & & \\
\hline $\begin{array}{l}\text { Step } 2 \\
\text { Before clean/ aseptic procedure }\end{array}$ & $\begin{array}{l}\text { Always } \\
\text { (n)\% }\end{array}$ & $\begin{array}{l}\text { Frequently } \\
\text { (n) } \%\end{array}$ & $\begin{array}{l}\text { Most } \\
\text { of the } \\
\text { time } \\
\text { (n) } \%\end{array}$ & $\begin{array}{l}\text { Sometimes } \\
\text { (n) } \%\end{array}$ & $\begin{array}{l}\text { Never } \\
\text { (n)\% }\end{array}$ & $\begin{array}{l}\text { No } \\
\text { Response }\end{array}$ & $\begin{array}{l}\text { Weighted } \\
\text { mean } \\
(\mathbf{W M})\end{array}$ \\
\hline $\begin{array}{l}\text { I wash my hands before gathering } \\
\text { equipment for procedures }\end{array}$ & $\begin{array}{l}(14) \\
36.0\end{array}$ & (13) 34.0 & $\begin{array}{l}(10) \\
26.0\end{array}$ & (0) 0 & $\begin{array}{l}(1) \\
2.0\end{array}$ & 2 & 4.0 \\
\hline I wash my hands before patient contact & $\begin{array}{l}(26) \\
70.0\end{array}$ & (10) 27 & (1) 3.0 & (0) 0 & $(0) 0$ & 3 & 4.67 \\
\hline I wash my hands before putting on gloves & $\begin{array}{l}(21) \\
56.7\end{array}$ & (9) 24.3 & $\begin{array}{l}(6) \\
16.2\end{array}$ & (1) 2.7 & (0) 0 & 3 & 4.33 \\
\hline $\begin{array}{l}\text { Before brushing the patient's teeth, } \\
\text { instilling eye drops, performing a digital } \\
\text { vaginal or rectal examination, examining } \\
\text { mouth, nose, ear with or without an } \\
\text { instrument, inserting a suppository and or } \\
\text { suctioning mucous }\end{array}$ & $\begin{array}{l}(28) \\
73.6\end{array}$ & (6) 15.7 & $\begin{array}{l}(4) \\
10.5\end{array}$ & (0) 0 & $(0) 0$ & 2 & 4.62 \\
\hline $\begin{array}{l}\text { Before preparing food, medications, } \\
\text { pharmaceutical products, sterile material }\end{array}$ & (32) 84 & (5) 13 & (1) 3 & (0) 0 & (0) 0 & 2 & 4.80 \\
\hline
\end{tabular}


Table 7. Compliance level responses of the respondents for step 3 about hand hygiene practice (mean of mean $=4.90$ )

\begin{tabular}{|c|c|c|c|c|c|c|c|}
\hline & Degree o & Compliance & & & & & \\
\hline $\begin{array}{l}\text { Step } 3 \\
\text { After body fluid exposure risk }\end{array}$ & $\begin{array}{l}\text { Always } \\
\text { (n)\% }\end{array}$ & $\begin{array}{l}\text { Frequently } \\
\text { (n)\% }\end{array}$ & $\begin{array}{l}\text { Most of } \\
\text { the time } \\
\text { (n)\% }\end{array}$ & $\begin{array}{l}\text { Sometimes } \\
\text { (n)\% }\end{array}$ & $\begin{array}{l}\text { Never } \\
\text { (n)\% }\end{array}$ & $\begin{array}{l}\text { No } \\
\text { Response }\end{array}$ & $\begin{array}{l}\text { Weighted } \\
\text { mean } \\
(\mathrm{WM})\end{array}$ \\
\hline $\begin{array}{l}\text { I wash my hands after handling } \\
\text { soiled dressings }\end{array}$ & (37) 97 & (1) 3 & (0) 0 & (0) 0 & (0) 0 & 2 & 4.96 \\
\hline $\begin{array}{l}\text { I wash my hands after performing } \\
\text { nursing procedures }\end{array}$ & $\begin{array}{l}(34) \\
87.1\end{array}$ & (5) 12.8 & (0) 0 & (0) 0 & (0) 0 & 1 & 4.86 \\
\hline $\begin{array}{l}\text { I wash my hands after taking of } \\
\text { gloves }\end{array}$ & $\begin{array}{l}(33) \\
84.6\end{array}$ & (4) 10.2 & (2) 5.1 & (0) 0 & (0) 0 & 1 & 4.79 \\
\hline $\begin{array}{l}\text { After removing an invasive medical } \\
\text { device }\end{array}$ & $\begin{array}{l}(38) \\
97.4\end{array}$ & (1) 0 & (0) 0 & (0) 0 & (0) 0 & 1 & 4.97 \\
\hline $\begin{array}{l}\text { After removing any form of } \\
\text { material offering protection } \\
\text { (napkin, dressing, gauze, sanitary } \\
\text { towel, etc) }\end{array}$ & $\begin{array}{l}(37) \\
97.5\end{array}$ & (0) 0 & (1) 2.5 & (0) 0 & (0) 0 & 2 & 4.93 \\
\hline
\end{tabular}

Table 8. Compliance level responses of the respondents for step 4 about hand hygiene practice (mean of mean $=4.65$ )

\begin{tabular}{|c|c|c|c|c|c|c|c|}
\hline \multicolumn{8}{|c|}{ Degree of Compliance } \\
\hline $\begin{array}{l}\text { Step } 4 \\
\text { After touching a patient }\end{array}$ & $\begin{array}{l}\text { Always } \\
\text { (n)\% }\end{array}$ & $\begin{array}{l}\text { Frequently } \\
\text { (n) } \%\end{array}$ & $\begin{array}{l}\text { Most of } \\
\text { the } \\
\text { time } \\
\text { (n) } \%\end{array}$ & $\begin{array}{l}\text { Sometimes } \\
\text { (n) } \%\end{array}$ & $\begin{array}{l}\text { Never } \\
\text { (n) } \%\end{array}$ & $\begin{array}{l}\text { No } \\
\text { Response }\end{array}$ & $\begin{array}{l}\text { Weighted } \\
\text { mean } \\
(\text { WM) }\end{array}$ \\
\hline I wash my hands after patient contact & $\begin{array}{l}(36) \\
92.3\end{array}$ & (3) 7.6 & (0) 0 & (0) 0 & (0) 0 & 1 & 4.91 \\
\hline $\begin{array}{l}\text { I wash my hands after leaving an } \\
\text { Isolated area }\end{array}$ & $\begin{array}{l}(38) \\
97.4\end{array}$ & (1) 2.5 & (0) 0 & (0) 0 & (0) 0 & 1 & 4.97 \\
\hline $\begin{array}{l}\text { I wash my hands after giving a patient } \\
\text { a bath }\end{array}$ & $\begin{array}{l}(36) \\
92.3\end{array}$ & (2) 5.1 & (0) 0 & (1) 2.5 & (0) 0 & 1 & 4.86 \\
\hline $\begin{array}{l}\text { I wash my hands after giving a patient } \\
\text { an injection }\end{array}$ & $\begin{array}{l}(28) \\
71.7\end{array}$ & (8) 20.5 & (2) 5.1 & (1) 2.5 & (0) 0 & 1 & 4.60 \\
\hline I wash my hands after feeding a patient & $\begin{array}{l}(30) \\
76.9\end{array}$ & $\begin{array}{l}(6) \\
15.3\end{array}$ & $\begin{array}{l}(2) \\
5.1\end{array}$ & $\begin{array}{l}(1) \\
2.5\end{array}$ & $\begin{array}{l}(0) \\
0\end{array}$ & 1 & 4.65 \\
\hline $\begin{array}{l}\text { I wash my hands after touching a } \\
\text { patients' notes }\end{array}$ & $\begin{array}{l}(17) \\
43.5\end{array}$ & (13) 33.3 & (6) 15.3 & (3) 7.6 & (0) 0 & 1 & 4.11 \\
\hline $\begin{array}{l}\text { I wash my hands after handling sputum } \\
\text { containers }\end{array}$ & $\begin{array}{l}(32) \\
84.0\end{array}$ & (4) 10.5 & (1) 2.6 & (0) 0 & $\begin{array}{l}(1) \\
2.6\end{array}$ & 2 & 4.72 \\
\hline $\begin{array}{l}\text { After performing a physical } \\
\text { non-invasive examination: } \\
\text { pulse, blood pressure, } \\
\text { auscultation, recording ECG }\end{array}$ & $\begin{array}{l}(23) \\
58.9\end{array}$ & (9) 23.0 & (6) 15.3 & (1) 2.5 & (0) 0 & 1 & 4.37 \\
\hline
\end{tabular}


Table 9. Compliance level responses of the respondents for step 5 about hand hygiene practice (Mean of mean=4.14)

\begin{tabular}{|c|c|c|c|c|c|c|c|}
\hline \multicolumn{8}{|c|}{ Degree of Compliance } \\
\hline $\begin{array}{l}\text { Step } 5 \\
\text { After touching a } \\
\text { patients' } \\
\text { surroundings }\end{array}$ & $\begin{array}{l}\text { Always } \\
\text { (n)\% }\end{array}$ & $\begin{array}{l}\text { Frequently } \\
\text { (n) } \%\end{array}$ & $\begin{array}{l}\text { Most of the } \\
\text { time } \\
\text { (n)\% }\end{array}$ & $\begin{array}{l}\text { Sometimes } \\
\text { (n)\% }\end{array}$ & $\begin{array}{l}\text { Never } \\
\text { (n) } \%\end{array}$ & $\begin{array}{l}\text { No } \\
\text { Response }\end{array}$ & $\begin{array}{l}\text { Weighted } \\
\text { mean } \\
(\mathrm{WM})\end{array}$ \\
\hline $\begin{array}{l}\text { I wash my hands } \\
\text { after touching a } \\
\text { patients' bed. }\end{array}$ & (22) 56.4 & (12) 30.7 & (5) 12.8 & (0) 0 & (0) 0 & 1 & 4.43 \\
\hline $\begin{array}{l}\text { I wash my hands } \\
\text { after touching a } \\
\text { patients' ventilator. }\end{array}$ & (21) 52.5 & (14) 35.0 & (5) 12.5 & (0) 0 & (0) 0 & & 4.39 \\
\hline $\begin{array}{l}\text { I wash my hands } \\
\text { after touching a } \\
\text { patients' IV }\end{array}$ & (23) 57.5 & (9) 22.5 & (5) 12.5 & (3) 7.5 & (0) 0 & & 4.29 \\
\hline $\begin{array}{l}\text { I wash my hands } \\
\text { after touching } \\
\text { patient's } \\
\text { belongings. }\end{array}$ & (20) 50.0 & (13) 32.5 & (5) 12.5 & (2) 5.0 & (0) 0 & 1 & 4.37 \\
\hline $\begin{array}{l}\text { I wash my hands } \\
\text { after touching a } \\
\text { patients' notes }\end{array}$ & (10) 25.0 & (15) 37.5 & (8) 20.0 & (7) 17.5 & (0) 0 & & 3.70 \\
\hline $\begin{array}{l}\text { I wash my hands } \\
\text { after clearing a } \\
\text { monitoring alarm }\end{array}$ & (12) 30.7 & (10) 25.6 & (9) 23.0 & (8) 20.5 & (0) 0 & 1 & 3.65 \\
\hline
\end{tabular}

3.2 Determining If There Is Any Relationship Between the Knowledge and Practice Levels With the Nurses' Demography.

The nurses' knowledge levels were compared with their selected demography namely age, Years of nursing experience in current post, Participation in a structured training session on hand hygiene for NICU environment, Length of time in the NICU, Level of Training in Perinatal/Neonatal Intensive Care Nursing and Highest level of Qualification. Table 13 indicated that the nurse's knowledge levels regarding HAI is related to the age $(\mathrm{p}=0.05)$, experience $(\mathrm{p}=0.023)$, length of time in ICU $(\mathrm{p}=0.043)$ and their education level $(\mathrm{p}=0.05)$. It is not significantly related to their participation in training nor level of training.

Table 10. ANOVA on Respondents' knowledge levels and their demographic characteristics

\begin{tabular}{|c|c|c|c|c|c|}
\hline Independent variables & $\begin{array}{l}\text { Sum } \\
\text { Squares }\end{array}$ & of $\mathrm{df}$ & $\begin{array}{l}\text { Mean } \\
\text { Square }\end{array}$ & $\mathrm{F}$ & Sig. \\
\hline Age & 16.418 & 2 & 8.209 & 6.798 & $.003^{*}$ \\
\hline Years of nursing experience in current post & 14.820 & 2 & 7.410 & 3.345 & $.046^{*}$ \\
\hline $\begin{array}{l}\text { Participation in a structured training session on hand hygiene for NICU } \\
\text { environment }\end{array}$ & .055 & 2 & .027 & .112 & .895 \\
\hline Length of time in the NICU & 14.045 & 2 & 7.023 & 4.194 & $.023^{*}$ \\
\hline Level of Training in Perinatal/Neonatal Intensive Care Nursing & 1.682 & 2 & .841 & .327 & .723 \\
\hline Highest level of Qualification & 6.103 & 2 & 3.052 & 4.080 & $.025^{*}$ \\
\hline
\end{tabular}


Similarly, the nurses' level of compliance to the HAI policies was compared with the selected demography namely age, Years of nursing experience in current post, Participation in a structured training session on hand hygiene for NICU environment, Length of time in the NICU, Level of Training in Perinatal/Neonatal Intensive Care Nursing and Highest level of Qualification. Table 14 indicates that none of the nurses' selected demography was associated with their level of compliance to HAI policies $(\mathrm{p}<0.05)$

Table 11. ANOVA on Respondents Compliance levels and their demographic characteristics

\begin{tabular}{|c|c|c|c|c|c|}
\hline Independent variables & Sum of Squares & df & Mean Square & $\mathbf{F}$ & Sig. \\
\hline Age & 1.929 & 2 & .964 & .603 & .552 \\
\hline $\begin{array}{l}\text { Years of nursing experience in } \\
\text { current post }\end{array}$ & 9.889 & 2 & 4.945 & 2.106 & .136 \\
\hline $\begin{array}{l}\text { Participation in a structured } \\
\text { training session on hand } \\
\text { hygiene for NICU environment }\end{array}$ & .129 & 2 & .064 & .265 & .769 \\
\hline Length of time in the NICU & 4.457 & 2 & 2.229 & 1.153 & .327 \\
\hline $\begin{array}{l}\text { Level of Training in } \\
\text { Perinatal/Neonatal Intensive } \\
\text { Care Nursing }\end{array}$ & .004 & 2 & .002 & .001 & .999 \\
\hline Highest level of Qualification & 4.032 & 2 & 2.016 & 2.508 & .095 \\
\hline
\end{tabular}

\section{Discussion}

The result from this study has indicated that knowledge among the studied subject is high with $62.55 \%$ of the nurses indicating knowledge of HH policies at the level of "Good" or "Excellent", compared to those showing "poor/average" knowledge levels at $37.5 \%$. This finding indicates that most of the respondents are aware that hand cleanliness remains the most effective measure for the prevention of cross infection in the health care setting (Ramasethu, 2017, Ghadmagahi, Zighaimat and Ebadi, 2011). Also, we found that knowledge is related to age, experience, and level of education. We note that the respondents were mostly nurses who were prepared at the level of degree and post graduate degrees and where mostly a good percentage of them have worked for more than 20 years. It is less surprising that the result showed such high knowledge levels which is consistent with Fashafsheh, Ayed, Eqtait and Harazneh (2015).

Also, we consider the findings that the mean compliance level of the nurses with the five (5) steps as recommended by the WHO is at 4.77 as very encouraging thus heeding to the five key moments when health care workers should wash their hands. These includes: Before touching a patient, before clean aseptic procedures, after body fluid exposure risk, after touching a patient and after touching a patient's surroundings all of which ensures good compliance (WHO 2017). We surmise that the respondents have the good awareness level, which perhaps informed their "beliefs" i.e. outcome evaluations, motivation to comply and power which are the elements of the Theory of Planned Behavior on which this study is hinged. Perhaps these elements were in play and enhanced the nurses' knowledge levels, as well as their compliance levels to hand hygiene at the hospital (Ajzen, 1991).

\subsection{Study Limitations}

We note that this study can be seen as a case study of an Island Hospital and may not accurately reflect what happens elsewhere on the Island as there is only one NICU in the Bahamas. We also note that the data used in this study is self-reported. We recommend that a more qualitative investigation be done.

\section{Conclusion}

This study revealed that nurses working at Neonatal Intensive Care Unit (NICU) of the Princess Margaret Hospital, Nassau, Bahamas are generally aware of the $\mathrm{HH}$ policies and exhibit good $\mathrm{HH}$ practice.

\section{Recommendations}

We recommend that a more qualitative study to investigate the policies, and extent of use of policies available at the ICUs in the hospitals. 


\section{Acknowledgements}

We are grateful to all the nurses in the Island hospital for their responses and to all the agencies and institutions who granted us the permission and approval to undertake the study

\section{Competing Interests Statement}

The authors declare that there are no competing or potential conflicts of interest.

\section{References}

Abedi, F., Namaei, M. H., Hamidi, Z., Soltani, M., \& Kiani, Z. (2020). Production and optimization of hand disinfection solution based on the World Health Organization formulation: a short article. J Birjand Univ Med Sci., 27(2), 210-15. [In Persian] https://doi.org/10.32592/JBirjandUniMedSci.2020.27.2.109

Ajzen, I. (1991). The theory of planned behavior. Organ Behav Hum Decis Processes, 50(2), 179-211. https://doi.org/10.1016/0749-5978(91)90020-T

Al-Rawajfah, O. M., Hewitt, J. B., Stetzer, F., \& Cheema, J. (2012). Length of stay and charges associated with health care-acquired bloodstream infections. Am $J$ Infect Control, 40(3), 227-32. https://doi.org/10.1016/j.ajic.2011.03.014

Arslan, U., Erayman, I., Kirdar, S., Yuksekkaya, S., Cimen, O., Tuncer, I., et al. (2010). Serratia marcescens sepsis outbreak in a neonatal intensive care unit. Pediatr Int, 52(2), 208-12. https://doi.org/10.1111/j.1442-200X.2009.02934.x

Bahamas Department of Statistics Bahamas. [Internet] (2014). Bahamas: Population \& census 2014. [cited 2018 Jan 25]. Available from http://www.bahamas.gov.bs/statistics

Burns, N. (1997). The practice of nursing research: conduct, critique \& utilization (3rd ed.). Nancy Burns, Susan K., \& Grove, S. K. (Eds.). Philadelphia: Saunders; 1997.

Cardo, D., Dennehy, P. H., Halverson, P., Fishman, N., Kohn, M., \& Murphy, C. L. (2010). Moving toward elimination of healthcare-associated infections: a call to action. Am J Infect Control, 38(9), 671-5. https://doi.org/10.1016/j.ajic.2010.09.001

Centers for Disease Control and Prevention. [Internet] (2018). Hand hygiene for healthcare settings 2018. Retrieved Nov 25, 2017, from http://www.cdc.gov/handhygiene

Centers for Disease Control and Prevention. [Internet] (2014). Eliminating healthcare-associated infections: state policy options.c2012. Retrieved May 10, 2014, from https://www.cdc.gov/hai/index.html

Centers for Disease Control and Prevention. (2011). Vital signs: central line-associated blood stream infections--United States, 2001, 2008, and 2009. MMWR Morb Mortal Wkly Rep. 2011, 60(8), 243-8. https://www.ncbi.nlm.nih.gov/pubmed/21368740

Cook, E., Marchaim, D., \& Kaye, K. S. (2011). Building a successful infection prevention program: key components, processes, and economics. Infect Dis Clin North Am., 25(1), 1-19. https://doi.org/10.1016/j.idc.2010.11.007

Fındık, E., Ceylan, M., \& Elmastaş, M. (2011). Isoeugenol-based novel potent antioxidants: Synthesis and reactivity. Eur J Med Chem, 46(9), 4618-24. https://doi.org/10.1016/j.ejmech.2011.07.041

Ghadmgahi, F., Zighaimat, F., Ebadi, A., \& Houshmand, A. (2011). Knowledge, attitude and self-efficacy of nursing staffs in hospital infections control. Journal Mil Med., 13(3), 167-72.

Jeong, I. S., Jeong, J. S., \& Choi, E. O. (2006). Nosocomial infection in a newborn intensive care unit (NICU), South Korea. BMC Infect Dis, 6, 103. https://doi.org/10.1186/1471-2334-6-103

Korniewicz, D. M., \& El-Masri, M. (2010). Exploring the factors associated with hand hygiene compliance of nurses during routine clinical practice. Applied Nursing Research, Elsevier 2010. https://doi.org/10.1016/j.apnr.2008.06.002

Mathai, E., Allegranzi, B., Seto, W. H., Chraiti, M. N., Sax, H., Larson, E., et al. (2010). Educating healthcare workers to optimal hand hygiene practices: addressing the need. Infection, 38(5), 349-56. https://doi.org/10.1007/s15010-010-0047-7

Mayhall, C. (2005). Hospital epidemiology and infection control (3rd ed.). Lippincott Williams; 2005.

Mehta, S., Rai, P. K., Rai, N. K., Rai, A. K., Bicanic, D., \& Watal, G. (2011). Role of spectral studies in detection of antibacterial phytoelements and phytochemicals of Moringa oleifera. Food Biophys, 6(4), 497-502. 
https://doi.org/10.1007/s11483-011-9231-2

McLaughlin, A. C., \& Walsh, F. (2012). Self-reported reasons for hand hygiene in 3 groups of health care workers. Am J Infect Control, 40(7), 653-8. https://doi.org/10.1016/j.ajic.2011.08.014

Mick, J. (2011). Promoting clinical inquiry and evidence-based practice: the sacred cow contest strategy. $J$ Nurs Adm., 41(6), 280-4. https://doi.org/10.1097/NNA.0b013e31821c479f

Mitra, D. K., Mullany, L. C., Harrison, M., Mannan, I., Shah, R., Begum, N., .. \& Baqui, A. H. (2018). Incidence and risk factors of neonatal infections in a rural Bangladeshi population: a community-based prospective study. J Health, Popul Nutr, 37(1), 6. https://doi.org/10.1186/s41043-018-0136-2

Parmeggiani, C., Abbate, R., Marinelli, P., \& Angelillo, I. F. (2010). Healthcare workers and health care-associated infections: knowledge, attitudes, and behavior in emergency departments in Italy. BMC Infect Dis, 10(1), 35. https://doi.org/10.1186/1471-2334-10-35

Polin, R. A., Denson, S., \& Brady, M. T. (2012). Strategies for prevention of health care-associated infections in the NICU. Pediatrics, 129(4), e1085-93. https://doi.org/10.1542/peds.2012-0145

Polit, D. F., \& Beck, C. T. (2014). Nursing research: Principles and methods (7th ed., p. 35-36). Lippincott William and Wilkins.

Princess Margaret Hospital. [Internet] (2017). Bahamas: Neonatal intensive care \& special care baby unit. Retrieved Feb 5, 2017, from http://pmh.phabahamas.org/services/in-patient-services/critical-care-units/neonatal-intensive-care-unit/

Rose, S., Spinks, N., \& Canhoto, A. (2015). Management Research: Applying the Principles (1st ed.). Routledge; 2015. https://doi.org/10.4324/9781315819198

Vermeil, T., Peters, A., Kilpatrick, C., Pires, D., Allegranzi, B., \& Pittet, D. (2019). Hand hygiene in hospitals: anatomy of a revolution. $J$ Hosp Infect., 101(4), 383-92. https://doi.org/10.1016/j.jhin.2018.09.003

World Health Organization. [Internet] (2017). WHO Clean hands net - a network of campaigning countries c2018. Retrieved Dec 27, 2017, from http://www.who.int/gpsc/national_campaigns/en/.

World Health Organization. [Internet] (2017). My Five Moments for Hand Hygiene. Retrieved January 3, 2017, from www.who.int/gpsc/tools/Five_moments/en/

World Health Organization. (2011). Health-care-associated infection in Africa: a systematic review 2011. https://doi.org/10.2471/BLT.11.088179

\section{Copyrights}

Copyright for this article is retained by the author(s), with first publication rights granted to the journal.

This is an open-access article distributed under the terms and conditions of the Creative Commons Attribution license (http://creativecommons.org/licenses/by/4.0/). 